\title{
HERITAGE INTERPRETATION: ANALYSIS OF LABOR HERITAGE IN THE CASE OF THAI LABOR MUSEUM (BANGKOK, THAILAND)
}

\author{
Siripen Yiamjanya
}

\author{
Suan Sunandha Rajabhat University, Bangkok, Thailand
}

Thai Labor Museum in Bangkok is the first and the only museum in Thailand that brings many aspects and issues about Thai laborers to public awareness. The heritage narrated in this museum regards the significance of Thai history and contemporary events that involve Thai laborers in the political and social context. The museum represents the historical realm of Thai labor and recognizes labor identities through their hard work and life. The purpose of this study can be determined through the following research questions: (1) how is the situation with the interpretation of heritage in the case of Thai Labor Museum?; and (2) what could be an alternative interpretation approach for labor heritage? The study used SWOT analysis framework as the method, carried out within the existing interpretation of the museum. Primary, secondary and tertiary interpretations were suggested. Also, critical issues and problems with interpretation at the site were addressed. Additionally, the study marks tourism route potential, connecting the museum with the historic railway factory heritage at Makkasan Workshop. Future development would create a new public and tourism precinct set amongst the backdrop of the industrial heritage of Thailand.

Keywords: heritage, interpretation, labor heritage, Thai Labor Museum

\section{Introduction}

Thai Labor Museum is located on Nikhom Rotfai Road, Makkasan, Ratchathewi. This museum used to be the railway and police station, and later became the office of the State Railway of Thailand Labor Union. It became the museum on October 17, 1993, after active discussions of many groups of stakeholders from both public and private sectors, scholars in the field of labor studies, historians and archivists, with a support of a German Friedrich Ebert Stiftung Foundation (FES).

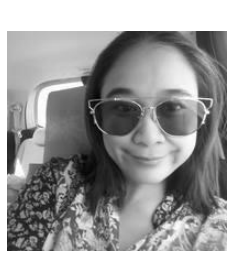

\section{Siripen Yiamjanya}

Ph.D. Architectural Heritage Management and Tourism (Silpakorn University, Bangkok, Thailand), Master of Arts in Tourism Management (Assumption University, Bangkok, Thailand)

Full- Time Lecturer and Head of Tourism Management Program in International College, Suan Sunandha Rajabhat University, Bangkok, Thailand

Personal interests: urban / cultural tourism, tourism logistics, heritage management, writing / literature

E-mail: siripen.yi@ssru.ac.th 
Outside the museum stands a monument called the Dignity of Labor, it shows a man and a woman pushing the huge wheel of history. The museum exhibits a historical background of Thai laborers in seven rooms: (1) Room 1 is about slave labors during the Phrai-Corvee system (Sakdina or Feudal System) which is the foundation of ancient Thai society; (2) Room 2 tells us about Chinese coolies, the locally sourced unskilled labors; (3) Then goes the room telling visitors about the reforms of Thailand during the reign of King Rama V as the major transitional period in Thai history; (4) Room 4 depicts the life of Thai laborers before and after the revolution in 1932; (5) Room 5 narrates about Thai laborers during the World War II and the Cold War; (6) Room 6 is about the October 14 uprising, the economic crisis and life of Thai workers during the prodemocracy period, with an emphasis on the labor of women and children, truck drivers and boxers; and (7) Room 7 is called the cultural room, it is dedicated to the story of a labor artist, Jit Phumisak who was one of the most significant thinker and intellectual of Thailand.

Between rooms 1-5 there is a tunnel that symbolizes a transition of Thai laborers from the past to more contemporary times. The key reason for selecting this museum for our study has been the fact that it is the only museum about Thai laborers in Thailand.

\section{Literature And Theory}

Heritage interpretation was first defined back in 1957 by Freeman Tilden in his book 'Interpreting our Heritage', as "an educational activity which aims to reveal meanings and relationships through the use of original objects, by first-hand experience, and by illustrative media, rather than simply to communicate factual information". After this Tilden's book was published, the term "heritage interpretation" has been defined in different ways, but his key principles are still widely adopted (European Association for Heritage Interpretation, 2018).

Heritage interpretation associates with sharing memories and experiences by connecting between people and places. Interpretation must be based on sound information and thematically organized, it also utilizes communication techniques that connect the interpreter, audience and the heritage resources. An interesting aspect in the interpretation of contemporary heritage is that it should promote the exploration of knowledge and ideas, and encourage reflection and debate (The National Trust of Australia (WA) and Museums Australia (WA) in partnership with Lottery West, 2007).

Interpretation also refers to the presentation of uniqueness of places or objects to public understanding, which can be for pleasure and enjoyment or for education. Effects of interpretation require good media (Praraththajariya, 2009).

Generally speaking, there are two key methods of heritage presentation. The first is guided interpretation through experience such as walks, talks, demonstrations and observations, performance, role playing, plays, poetry readings, dance and music, other activity programs, special events. The second one is self-guided programs. Many museums and heritage sites apply this method and many visitors also tend to prefer this method. The method includes publications, exhibitions, information panels and site-specific interpretation boards, signage system, graphic illustrations such as artworks, photographs, maps, and other visual materials, computer interactive and video games. This method highly stimulates visitors' interaction with the heritage place and the related objects.

Another perspective of heritage interpretation is that its main aim is not instruction, but rather provocation. To communicate significant ideas about a place or a phenomenon to 


\section{HERITAGE INTERPRETATION:}

public audience, heritage interpretation can be designed in a systematic way or in an informal educational way, thus establishing both cognitive and emotional links between the audiences/ visitors and the heritage (Lakerveld \& Gussen, 2016). It is especially so if heritage sites, objects or phenomena being interpreted may not be attractive or have some sensitive cases or are representing hostile concepts.

In this case, the emotional effect of interpretation is the most significant. In the case of Thai Labor Museum, narratives of labors in historical, social, cultural, political and industrial dimensions are being told, whereas objects in the museum are only the primary means to demonstrate the core ideas.

\section{Methods}

The purpose of this study was identified through the following research questions: (1) how is the situation with interpretation of heritage in the case of Thai Labor Museum? and (2) what could be an alternative interpretation approach to labor heritage? Our study has used SWOT analysis framework as the central method.

\section{Results}

\section{Heritage Background of the Site}

The physical building of the museum is significant itself as it was formerly the office of railway police station with a prison. Later, this place was used as the office of the Labor Union of State Railway of Thailand for many years. This museum narrates the plights of Thai laborers in different periods of time, which Thailand had been through. The heritage of this museum regards the significance of Thai history and contemporary events that involve Thai laborers in the political and social context.

The museum is also the first and the only museum in Thailand that demonstrates many aspects of Thai laborers' life that have been almost ignored in the society, thus bringing them closer to public awareness. Interpretation is how we manage and understand our heritage. In the case of Thai Labor Museum, laborers seem to be viewed as a human (labor) heritage, these are ordinary people working on the construction of national infrastructure. The museum reflects Thai laborers' hopes and voice for equal rights in the society and advocates that the public sector (i.e., the government) and the private sector (employers) should take more care of laborers, particularly in terms of their social welfare, physical safety and security at work.

\section{The Existing Interpretation}

First thing one can see arriving at the museum is the monument/statue under the name of "The Monument of Labor Dignity". The monument was built to express the dignity of Thai laborers and to honor them. It portrays a man and a woman helping each other with pushing a heavy wheel to move forward. This wheel is crushing the military tank. This is a symbolic act telling us that Thai history has been driven forward by various groups of Thai laborers, while also sending the message of anti-dictatorship since the military tank is often seen as the symbol of military regime. This monument is an integral part of the whole museum interpretation, rendering an image of government and manufacturing businesses as the protagonists to Thai laborers. 
A little further on the left, there is a tourist attraction sign supplied by the authority. It tells us that this attraction is a museum type of attraction. However, this is not quite rational because it appears as a picture of earthenware.

What should be noted about this place is its location that is not included in the tourism enclave, it is not like many other museums in the Bangkok old quarter. The museum is located in the place that creates a marginal feeling around the Makkasan area, the local view is suppressed by the toll road above the building and the decayed urban environment surrounding the museum. This environment around the museum is quite ironic because it perfectly matches the story inside the museum itself. This feeling continues when we step inside the museum.

The physical location and the building emphasizes the narratives of the story presented in the museum. At the entry point, the museum creates a ghostly feeling due to its dark and dim atmosphere. Stepping through an old glass sliding door leads first to a small area inside that may be considered as a foyer. There is a small notebook on the reception counter for the visitors to leave their feedback and comments about the museum. This is good as visitors can express their feelings right after the visit. This is also beneficial for the museum management as they are receiving immediate descriptive responses from the visitors. As the author personally observed, many people expressed their positive and cheerful feelings about the museum, and also sympathy to Thai workers.

The orientation around the museum is very simple: a staff member in casual clothes comes out to welcome and gives visitors brochures. Each of the six rooms in the museum depicts the evolution of the labor movement and the fight to obtain fair treatment. The continuity of the interpretive content in each room is quite strong, arranged in accordance with the main events of the country including the reforms under the reign of King Rama V, the Siamese Revolution in 1932, the October 14 uprising, and the World War II and the Cold War. Designing the exhibitions in several rooms is good because the whole outline can be thus divided into smaller themes.

This helps the visitors to structure their walkthrough. In each of six exhibition rooms, there are many old documents such as news, contract papers, governmental announcements, and other old artifacts on display. This helps with building up the feelings of both incongruity and sorrow about the hardships and poverty of Thai laborers.

A combination of these six rooms gives a sense of sequence in the historical content. Each room has a clear portrayal of its socio-cultural context.

At the same time, we need to mention here that the visual environment seems to be less effective. If visitors expect to receive some knowledge about Thai laborers, the museum plays this role very well. Contrarily, the displays of objects cause some confusion and distraction among the visitors. For example, the first room exhibits the life of slaves during the Phrai- Corvee system: there are some artifacts of earthenware there, a model of Chedi and a collection of agricultural equipment. If the staff does not immediately tell visitors why these objects are even displayed here, the visitors might not understand the linkage at all.

Everything has its center: the universe, the world, countries, cities, people, objects and pieces of text. The idea of a center is important and vital, as the center provides the focus (Hall, 2012).

In contrast to center, margin provides limits, edges, borders and boundaries. Once entering the first exhibition room, the idea of its center is not immediately obvious. The position that seems to be the center of the whole display demonstrates the two traveling cases 


\section{HERITAGE INTERPRETATION:}

that block the eyes from seeing the core theme of the room. In contrast, the room no. 4 which depicts the life of Thai laborers before and after the revolution in 1932, applies the idea of center quite successfully - with the help of a glass exhibition box in the middle of the room displaying old documents, surrounded by the posters narrating many transitional events that affected Thai laborers before and after the revolution of 1932.

An interesting thing that should have been exhibited in a more outstanding manner is an iron knot or an emblem which was cast as the memorial of the Siamese Revolution of 1932 (or the so-called the Siamese coup d'état), the turning point in Thai politics. Today the real one is embedded at the Equestrian Statue of King Rama V the Great.

Regarding the use of technology, there are audio- and visual kiosks installed to demonstrate the work laborers, however, sadly, these devices are not actually operating. The museum thus lacks the visual element in its interpretation. A certain level of visual experience is provided by a collection of small 3D icons exhibited to demonstrate workers at work in each historical period.

The largest section is the section on the right side of the museum when entering it. It may be considered as the section that is creating a tertiary experience of the museum's interpretation for visitors. This part of the museum is dedicated to more contemporary issues of Thai workers' history, for instance, the problems of child and female workers, events and activities related to Thai workers, social welfare issues, including the unforgettable tragedies occurred at clothing factories due to the poor working conditions or nonconformity to basic safety regulations.

Even though the display of this section does not provide plenty of information, the display of the burned stuff such as dolls produced in the factory in a glass box contributes to very much effective/impressive interpretation which leads to an emotional response among visitors. This can be a good marker, with a symbolic meaning. The visitors looking at these burned dolls usually start thinking beyond what appears in front of them in relation to other, similar events in the society. The box above this display shows us the number of workers who died in the fire events, other factory fire accidents and also some pictures of the losses.

There is also a truck model exhibited there to tell about the life of truck drivers, which is a very typical Thai labor profession. Contrarily, the story of boxers as workers was also well explained, even though without an impressive presentation to support the story.

The most impressive sections of this museum include room no.7 which is called the cultural room, as it is dedicated to the story of a labor artist, Jit Phumisak who was one of the most significant thinkers and intellectuals of Thailand.

Other important parts of the museum are the transitional tunnel and a corner in the room about the World War II and the Cold War.

The room of the labor artists plays its role in the interpretation as a more relaxing space which tells us about the aesthetic side about Thai laborers' life. Folk songs have always been a voice of the marginalized part of Thai society, including various groups of workers.

The songs reflect the marginalized people's lives of Thailand, especially after the 1930s, the period that marks the political change from monarchy to constitutional monarchy in the country. Most of the songs emphasize on the equal rights for groups of people, normally farmers, factory workers and laborers who have been then facing severe social exclusion. This is impressive that the life of workers, being so heavily marginalized, still had sufficient space for aesthetics. Physically, this room is small, and has its intrinsic value as the 
former prison cell. The iron door in the room is an original one, as this building used to be the prison.

The transitional tunnel creates a sense of changes, enhancing visitors' emotional linkage about the flow that changes many aspects in life, including the roles of Thai workers during more present time. The tunnel leads the visitors to the largest room where the stories cover how Thai workers have taken actions and new social roles in an attempt to push their lives for the better, for example, the roles of women workers, establishment of various labour organizations and associations, introduction of new laws. However, we also need to note that the content of this room is not exactly up-to-date and can be renovated.

A corner in the room dedicated to the events of the World War II and the Cold War displays a collection of magazines from the old days concerning the transition of the Siam during and after the war. What is interesting, at least as for the author's perception, is that those magazine covers show the coverage about the communism and the "American Life" displayed in a cage. This creates a contradictory feeling towards "American Life" (questioning what is freedom?).

Also, this corner gives a sense of anti-communism represented by the magazines and posters with a question raised as "communism or freedom". The American Life magazines seems to have been significant due to the satire directed at the modernization, capitalism and the American Dream that have changed many facades of Thailand since then.

Located next to the cage is an exhibit of a hair salon, representing the new way of life for Thai people that changed to something much closer to materialism (working in a hair salon rather than in rice field, for instance). Hair salon becomes a metaphor of materialism that, inter alia, places more value on physical beauty. The overall feeling towards this room is like being in a cinema that shows a documentary film.

The major significance of this museum is that it tells the story of laborers in the historical timeline of Thailand. Not all objects are actually old artifacts like in some other museums that display truly ancient artifacts. This makes it harder for the museum management group to design an interpretation as it is all based on situations and events that cannot be easily recreated (even though there are some old documents on display). On the other hand, what is now being displayed in the museum can actually happen again anywhere in our society. This means that the museum needs a creative process for representation of laborers in Thailand. The core message is both social and contemporary: social significance is that the society needs to value laborers more.

These days the museum is not popularly viewed as a tourist attraction, but rather as a center for those who would like to get a new perspective on the world of laborers in Thailand. It is not the place to entertain oneself, but rather to cultivate some feelings and senses as well as an understanding towards a group of people in society who have been, for a long term, treated as marginalized people. The interpretation of Thai Labor Museum may form a solid mental representation about Thai laborers overall. Visitors could obviously feel that the social group of Thai laborers is associated with hardships, unsafe work conditions, and unfair treatment.

\section{SWOT Analysis of the Existing Interpretation Strengths}

-The museum is the only one museum and learning center dedicated to the issues of Thai laborers; 


\section{HERITAGE INTERPRETATION:}

-There are old papers and documents telling us about events and situations in the history of Thai laborers;

-The museum provides the content that containts knowledge and provokes feelings at the same time;

-The location is easily accessible for any interested visitor;

-The museum's website has solid optimization which guarantees strong presence in the main search engine (for example, within Google.co.th this museum can be easily found using the keywords "labor museums in Thailand", "labor museums in Asia" or even simply "labor museums").

-The museum is actively using social media platforms, Facebook being one of its key communication channels.

-The museum organizes public lectures, traveling exhibitions and outdoor activities, thus helping the interpretation with reaching more audiences.

-The museum management and staff have a strong will and a solid vision which help them promote the principles of well-being and equal rights of Thai workers.

-The museum serves as a community which groups people with common interests so that to get them involved in museum's interpretive activities.

\section{Weaknesses} building).

-The place is very small, thus, the museum is very limited in space (a single-store

-Even though it is located in Bangkok downtown, it does not have downtown presence. The building is very discreet and unnoticeable for passers-by. We can even state that, to some extent, it is located in an abandoned environment of Bangkok.

-Its location does not encourage a pleasure walk around.

-The interpretation deals with too many objects and too much information, all in one small space.

-The museum is very limited in the use of technology for its interpretation.

- Its location is not included in the popular tourist cluster, and this fact reduces the number of potential visitors.

\section{Opportunities}

-The theme of the museum will be always contemporary in perception by the society since labor issues are often covered by the news.

-The museum will be soon re-established as part of a bigger museum to be managed by the State Railway of Thailand (as we were informed by a museum staff member).

-The government today is much more concerned about the well-being of Thai laborers. This may contribute to future popularity of the museum.

- More of information technologies can be applied in marketing and public relations of the museum.

-There are international organizations that support the museum and its voice, primarily because of their concerns with contemporary labor issues.

-There are interested groups/parties that may get involved as official partners of the museum (and, for example, to form a foundation).

-There can be educational institutions that may use the museum as a learning center for their students. 
-General public, representing various social and/or political groups, may start to be more interested in learning about Thai culture and the life of traditional Thai laborers. This will surely promote the ideas of social caring and sharing across wider groups of people. This can indirectly support the museum's interpretation and its communication with the public/society.

-There is a growing trend of urban tourism that will surely give more room for different city museums, including this one.

-Urban regeneration trend provokes more of public awareness and interest in making urban decay areas more vibrant through different social and cultural activities.

-Railway factory heritage at Makkasan Workshop (nearby the museum) and its future development would create a new public and tourism precinct as an integral part of Thai industrial heritage.

\section{Threats}

- The museum's territory is vulnerable because it might become subject to demolition of buildings due to new land use needs, despite the fact that the museum building has both social and political significance.

-The museum does not belong to any communities around. So there is no involvement on the part of local communities in the neighborhood.

-The area where the museum is located has the image of urban decay around it.

-There is very limited recognition of the marketing efforts of the museum and its staff.

\section{Discussion}

\section{Suggestions concerning Interpretation}

(a) Primary interpretation

-The space at the museum entrance could be used more effectively.

-Visual display is significant. Letters should be sized in a way that invites visitors to read. Maps with interesting facts and figures can be used, so visitors can easily get the most important information during their (normally) short visit. Moreover, objects of significance should be placed on the most favorable positions.

-Some objects should be removed to allow more spaces for more important ones.

-Guided walk tours may not be easily designed due to narrow spaces, but it still can be arranged as a trail through the rooms. Because of this space limitation, self-walk or selfguided tours are what is currently recommended for visitors. However, such self-guided walks lack efficiency since some of the artifacts have no information at all. In other places, the displays cannot convey well enough why these artifacts are exhibited there or how they are significant. In other words, significant objects need more detailed information on them.

-Some parts of the content need regular updates that would incorporate more contemporary issues.

(b) Secondary interpretation

-A suggestion based on the idea of center could be the following: in each room there must be a central icon at the center of the room, as this draws visitors' attention to approach and look at the central spot. The meaning of this central object should be visually obvious at a first glance. Moreover, the central image should convey the overall theme of the room. 


\section{HERITAGE INTERPRETATION:}

-There is plenty of information on the Internet about Thai laborers, from the history and up to contemporary events. Interested visitors can search and retrieve more of such information from various online sources. Thus, they do not really have to visit the museum as such. This means that the museum should put more effort in techniques of displaying objects and creating a special atmosphere through light and installations that would affect visual and spiritual experiences. The museum already has quite a lot of content. What it needs now is to provoke deeper feelings of visitors towards the situations Thai workers have been facing.

-There must be a logical connection in interpretation from the pre-entry stage until the end of a visit. The sculpture in front of the museum expresses the significance of Thai laborers as the national workforces, and this message should be repeated in interpretation throughout the visit.

(c) Tertiary interpretation

-The last room should surely dedicate more spaces for the section about the King's Philosophy of Sufficiency Economy and the alternative living of Thai workers. Currently, there is only a huge model that was designed to demonstrate local living through a house in vernacular style and some agricultural equipment below. These objects alone cannot fully convey this message unless the staff provides additional information. The museum needs to re-interpret the King's Philosophy and makes its ideas more outstanding, explaining in detail the reason why this philosophy becomes significant to Thai workers during our days. The interpretation of this section can be made both more enjoyable and meaningful. The museum can design an interpretation by narrating the story with use of symbols how the King's Philosophy can promote workers' quality of living. This will surely also benefit students' learning about the King's Philosophy.

-As the main audiences of the museum are schools and universities, displays should not have too much depressing atmosphere. Some rooms may be actually redesigned to become more friendly and more appropriate as the learning environment.

-The museum does not really provide individual enjoyment during the visit, primarily due to its dark atmosphere. At the same time, even though the whole theme of the museum is hard life of Thai laborers, the museum can also include a more positive interpretation, for example, pleasant and/or happy aspects of Thai workers' life. This will surely contribute to entertaining visitors, not disregarding the fact that the museum has a serious story to tell at the same time.

-Tourism and leisure connection can be also addressed. Tourism becomes a useful and contemporary tool motivating the locals to interpret their heritage and/or their culture to those who do not belong here. As urban tourism has been growing in the postmodern era, the museum has been experiencing the so-called "Heritage Effect" when groups of people seek for their identities and would like to express their needs and feelings through their quest of significance.

This time would be also the most appropriate time for the museum to incorporate current tourism trends in its interpretation plan. Despite the limited space available, the museum should find space for more of visitors' participation and engagement in creative arts and cultural activities that are directly related to the living of Thai workers. The museum can also apply various creative activities such as arts and music that would involve groups of volunteer workers. Moreover, the museum can run traveling exhibitions with the most interesting and relevant themes, linking its work with other museums as part of their joint 
tourism promotion. Moreover, the environment outside the museum itself should be improved to increase urban friendliness and walkability.

-The majority of rooms in the museum narrate the past events. This can stimulate some nostalgia among visitors. Drawing visitors' attention back to the past assumes a combination of suffers, joys and changes in personal perception and attitude about laborers. This does not mean that the museum needs to change the whole theme about Thai laborers (primarily, the fight for equal rights). Little by little, some additional elements can be added to make sure the museum's visitors appreciate the past culture of Thai laborers. Actually, there is already a room in the museum that seems to represent this (the Room of Jit Phumisak). However, as of today, this room only displays the music instruments that Jit Phumisak used for playing songs about Thai laborers, some folksongs and things like that. The interpretation of this room should be somewhat redesigned to incorporate more of folk cultural activities. For example, once visitors are entering the room, instead of a static display, some folk songs and other music can be added.

-A living exhibit could be one of another interesting ideas to suggest to the museum. Living exhibit can be defined as the organization of a structured exhibit in a defined area, which usually places an importance on living heritage primarily (Jafa, 2012). Since the museum heritage concentrates around humans (the human assets of the society), such a living exhibit could be very much appropriate.

-Contemporary stories, especially positive stories about current living of Thai laborers should get more attention. It would appropriate to display how Thai laborers can be currently supported and empowered. Also, more information on their present contribution to the society in various dimensions can be added. Some questions should be left open for the visitors so that they can reflect further, after their visit to the museum.

-Visitors' feedback can be also very useful for the museum's interpretation. The museum may arrange a monthly exhibition of the left feedbacks and photos of the visitors at the foyer hall of the museum. Also, the museum may provide small souvenirs (something with the museum logo) for the visitors in exchange for their testimonials.

\section{Conclusion and Directions for Future Research}

As it is obvious from all of the above, there are some critical issues and problems with interpretation at the museum site. The first and most important one concerns the limitation in the museum's space and its location (the surrounding areas primarily). This may limit the museum's competency in improving its interpretation and spatial design.

There must be truly original ways to maximize the existing space for better interpretation that could provide more insights and meanings to visitors. Minimum use of objects can also contribute to greater effect on visitors. The museum building alone has the value of its own as it used to be the police station and the prison during the times of critical transition of Thailand. Therefore, the significance of the museum building itself should have been documented and explicitly narrated.

Another interesting opportunity associated with heritage and urban tourism is that the museum is situated along the railway landscape connected with the historic factory at Makkasan Workshop which has currently been in focus in the context of urban and industrial heritage revival development. 


\section{HERITAGE INTERPRETATION:}

This study therefore marks the historic and industrial heritage tourism theme route potential. Future development of urban tourism in Thailand overall and in Bangkok in particular would open up brand new opportunities to narrate the story of the industrial heritage of Thailand. One this starts to take place, further studies in this direction can be carried out.

\section{References:}

European Association for Heritage Interpretation (2018). Definition of interpretation. Retrieved from http://www.interpret-europe.net/feet/home/heritage-interpretation/definition

Hall, S. (2012). This means this, this means that: a user's guide to semiotics. Great Britain: Laurence King Publishing Ltd.

Jafa, N. (2012). Performing heritage: art of exhibit walks. New Delhi: SAGE Publications Pvt Lid.

Lakerveld, J.V. \& Gussen, I. (2016). Developing an introductory meeting/workshop on heritage interpretation for professionals and volunteers in the heritage sector: the guidelines. Retrieved from http://www.interpretingheritage.eu/sites/default/files/InHerit-guidelines.pdf

Praraththajariya, K. (2009). The design of English materials to communicate the identity of Bang Poo Seaside Resort for sustainable tourism. Retrieved from http://www.ssruir.ssru.ac.th/bitstream/ssruir/390/1/107-53.pdf

The National Trust of Australia (WA) and Museums Australia (WA) in partnership with Lottery West (2007). Sharing our stories: guidelines for heritage interpretation. Retrieved from https://www.nationaltrust.org.au

Paper submitted

Paper accepted for publishing

Paper published online
11 October 2020

22 November 2020

31 January 2021 